\title{
Drilling cores on the sea floor with the remote-controlled sea floor drilling rig MeBo
}

\author{
T. Freudenthal and G. Wefer \\ MARUM Center for Marine Environmental Sciences, University of Bremen, Bremen, Germany \\ Correspondence to: T. Freudenthal (freuden@marum.de) \\ Received: 11 June 2013 - Published in Geosci. Instrum. Method. Data Syst. Discuss.: 1 July 2013 \\ Revised: 9 December 2013 - Accepted: 9 December 2013 - Published: 20 December 2013
}

\begin{abstract}
The sea floor drill rig MeBo (acronym for Meeresboden-Bohrgerät, German for sea floor drill rig) is a robotic drill rig that is deployed on the sea floor and operated remotely from the research vessel to drill up to $80 \mathrm{~m}$ into the sea floor. It was developed at the MARUM Research Center for Marine Environmental Sciences at Bremen University. The complete system - comprising the drill rig, winch, control station, and the launch and recovery system is transported in six containers and can be deployed worldwide from German and international research ships. It was the first remote-controlled deep sea drill rig to use a wireline coring technique. Compared to drilling vessels this technology has the advantage of operating from a stable platform at the sea bed, which allows for optimal control over the drilling process. Especially for shallow drillings in the range of tens to hundreds of metres, sea bed drill rigs are time-efficient since no drill string has to be assembled from the ship to the sea floor before the first core can be taken. The MeBo has been successfully operated, retrieving high-quality cores at the sea bed for a variety of research fields, including slope stability studies and palaeoclimate reconstructions. Based on experience with the MeBo, a rig is now being built that will be able to drill to a depth of $200 \mathrm{~m}$.
\end{abstract}

\section{Introduction}

Conventional methods of sampling the sea floor from research ships include the use of vibracores, gravity cores and piston cores. With these robust and reliable instruments, cores with lengths of 5-15 $\mathrm{m}$ (up to $50 \mathrm{~m}$ in rare cases) can be retrieved in areas of unconsolidated sediments on the sea floor (Hebbeln, 2003). Dredging is used to collect blocks of hard rock lying on the sea floor.

Drilling ships are usually employed when longer sediment cores are necessary or if cores from hard-rock provinces are targeted (Hebbeln, 2003). These ships can drill cores down to several hundred metres, or even kilometres deep. However, the use of drilling ships is expensive and not efficient for shallow drilling needs (McGinnis, 2009). Before the actual drilling process can begin, a drill string has to be assembled that extends from the ship to the sea floor. Vibrations in the drill string and movements of the ship prevent optimal control of the drill-head pressure, which considerably compromises the core quality, especially in the upper tens of metres.

There are increasing needs both in research and industry for shallow drilling (Sager et al., 2003; Yetginer and Tjelta, 2011). The construction of foundations and anchors for offshore installations is very dependent on the geotechnical properties of the sea floor. Exploration for mineral deposits such as sulfide mineralization around hydrothermal systems or investigations of methane hydrate deposits also require the drilling of numerous shallow holes (Ishibashi et al., 2007; Spencer et al., 2011). Palaeoclimate studies are enhanced by the ability to obtain cores that are longer than those from conventional methods because the marine sediments are an archive for the reconstruction of past environmental conditions. Studies of three-dimensional structures on the sea floor, such as mud volcanoes and slope slumps, require a large number of shallow holes that cannot be effectively cored either by the conventional methods on current multi-purpose research vessels or by drill ships. 


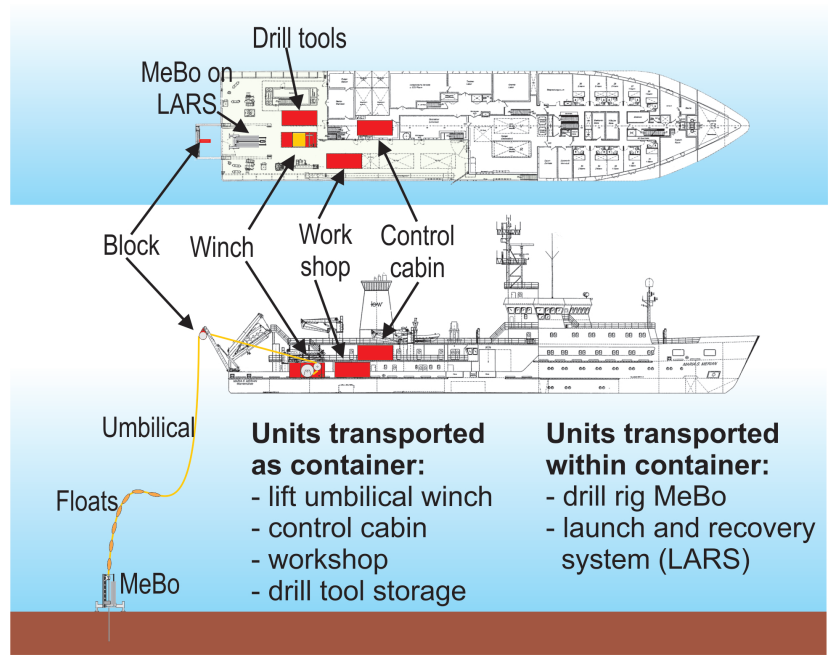

Fig. 1. Typical operational setup for a remote-controlled drill rig that is lowered to the sea floor. As an example, the sea floor drill rig $\mathrm{MeBo}$ and the research vessel Maria S. Merian is shown.

\section{Examples and advantages of robotic drilling systems}

Robotic drilling rigs that are lowered onto the sea floor from multi-purpose research vessels and that retrieve cores from the sub-bottom by remote control from the ship (Fig. 1) can help to fill the gap between relatively inexpensive conventional methods - like vibracoring, gravity coring or piston coring - and the use of drill ships. For deployment on the sea floor, several drill rigs have been developed that use a single core barrel and can drill to a depth of up to $5 \mathrm{~m}$, as well as other rigs that have a drill-pipe magazine (multi-barrel). For the latter, extension pipes can be attached to the drill string and thus significantly greater coring depths can be achieved.

To our knowledge, the first example of a remotely operated sea floor drill rig was the MARICOR, developed in 1973 by Atlas Copco. This rig was configured for deployment on continental shelves down to $200 \mathrm{~m}$ water depth and a drilling depth of $60 \mathrm{~m}$ using a diamond rotary drilling method.

The British Geological Survey (BGS) operates two singlebarrel drill rigs (Wilson, 2006). The $5 \mathrm{~m}$ rock drill (RD1) was developed in 1982. A smaller $1 \mathrm{~m}$ drill can retrieve an oriented core for palaeomagnetic studies (MacLeod et al., 2002). In 2006 the BGS developed a multi-barrel rig that could drill to a depth of $15 \mathrm{~m}$ (Wilson, 2006) and has now been upgraded for a drilling depth of $50 \mathrm{~m}$.

In 1989/1990 the American company Williamson and Associates built a $3 \mathrm{~m}$ drill rig (Johnson, 1991), and in 1996, 2005 and 2008 they produced the Benthic Multicoring Systems BMS-1, BMS-2 and BMS 3, respectively. The BMS drills are operated on the research ship Hakurei No. 2 by the Metal Mining Agency of Japan and can drill to a depth of $20 \mathrm{~m}$ (Ishibashi et al., 2007) in unconsolidated sediments or in hard rocks. In 2008 Williamson and Associates developed a sea bed drill rig called an Autonomous Coring System
(ACS) for the National Institute of Ocean Technology in India designed for recovering up to $100 \mathrm{~m}$-long cores at $3000 \mathrm{~m}$ water depth.

The Australian company Benthic Geotech Pty Ltd has been operating the Portable Remotely Operated Drill (PROD) since 1997, a multi-barrel drill rig that can retrieve cores up to $100 \mathrm{~m}$ long in unconsolidated sediments or hard rocks (Stuart, 2004; Pallanich, 2010).

In 2011 the Californian company Gregg Drilling together with several companies, including Marl Technologies and Schilling Robotics, developed the Gregg sea floor drill for up to $150 \mathrm{~m}$ deep drilling for geotechnical purposes.

All of the described drill rigs are controlled and supplied with energy from the ship through a special steel-armoured cable. These drilling tools present new possibilities for sampling from conventional research ships. The multi-barrel rigs are especially well suited for filling the growing need by both marine research and offshore industry for cores of 30-100 m length on the continental shelf areas as well as in the deep sea. These remote-controlled drills have significant advantages over drill ships.

- Ship and drill-string motion due to wind, currents and waves do not affect the quality of the drilling process because the work is done from a stable platform on the sea floor.

- Robotic drill rigs can be launched from various available multi-purpose research ships. This can reduce the mobilization costs for worldwide deployment.

- As a rule, drilling ships are expensive and heavily booked. By avoiding the time-consuming assembly of a drill string from the drilling ship to the sea floor, the use of drill rigs placed on the sea floor can be substantially more time- and cost-effective.

A similar concept to the remote-controlled drilling on the sea floor is implemented by drills mounted on submarine robots (remotely operated vehicle, ROV). The ROV is connected to the vessel by an umbilical and is used for navigation, data transfer, and supply of hydraulic energy for the drill rig. The MBARI ROV-mounted rig can drill horizontal cores with a maximum length of $1 \mathrm{~m}$ (Stakes et al., 1997). The Rovdrill ${ }^{\circledR}$, which was developed by Perry Slingsby, drills vertically and can attain depths of up to $20 \mathrm{~m}$. The third generation of this development, called Rovdrill 3, is designed for a maximum coring depth of more than $80 \mathrm{~m}$ (Spencer et al., 2011).

\section{The sea floor drill rig MeBo}

From 2004 to 2005, the sea floor drill rig MeBo (Fig. 2; Table 1) was developed at the MARUM Center for Marine Environmental Sciences at Bremen University with funding from the Federal Government of Germany (Education and Research) and the State of Bremen (Freudenthal and Wefer, 


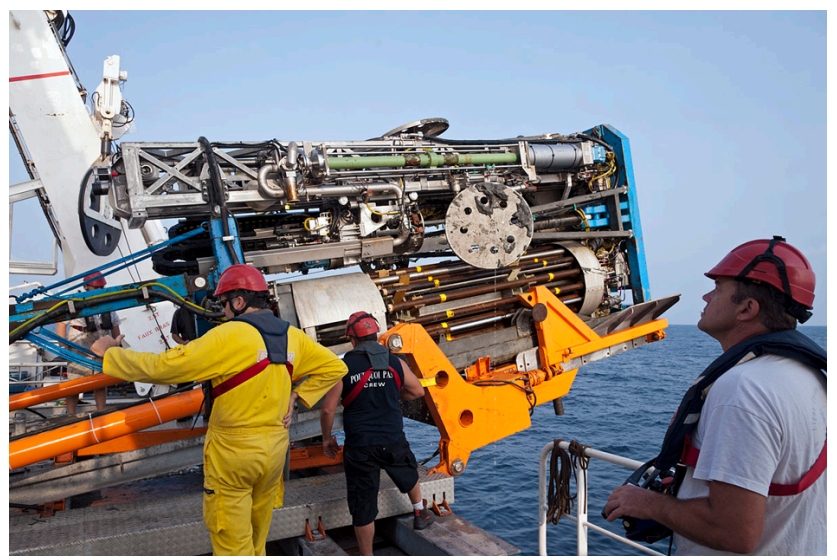

Fig. 2. The sea floor drill rig MeBo during the deployment start from the research vessel RV Pourquoi Pas? in November 2011 (photo: T. Klein, Marum).

2007). MeBo is the acronym for Meeresboden-Bohrgerät, German for sea floor drill rig. This is the first drill rig developed and operated by a scientific institute that can drill cores up to $80 \mathrm{~m}$ deep in unconsolidated sediments and in hard rocks. It is the first robotic deep sea drilling rig in the world that can drill cores using both conventional and the advanced wireline methods.

As far as is possible, the MeBo uses proven technology that has been time-tested in onshore drilling systems or on commercial ROVs. Special requirements for its construction included the following:

- convenience of transportation on land and sea,

- $10 \mathrm{t}$ maximum weight,

- drilling capability in both unconsolidated sediments and hard rocks,

- drilling depth of at least $50 \mathrm{~m}$,

- core diameter of 50-80 mm,

- deployment depth up to $2000 \mathrm{~m}$ (with the option to $4000 \mathrm{~m})$

It was developed in close cooperation with the companies Prakla Bohrtechnik GmbH and Schilling Robotics. The German company Prakla Bohrtechnik GmbH in Peine was primarily responsible for the mechanical and hydraulic development. The California-based company Schilling Robotics developed the core-barrel magazine with the loading arm and also provided the telemetry system for data transfer and operating energy. MARUM was responsible for the system design, energy supply and deployment concept and also developed the control system (hardware and software) for the MeBo.

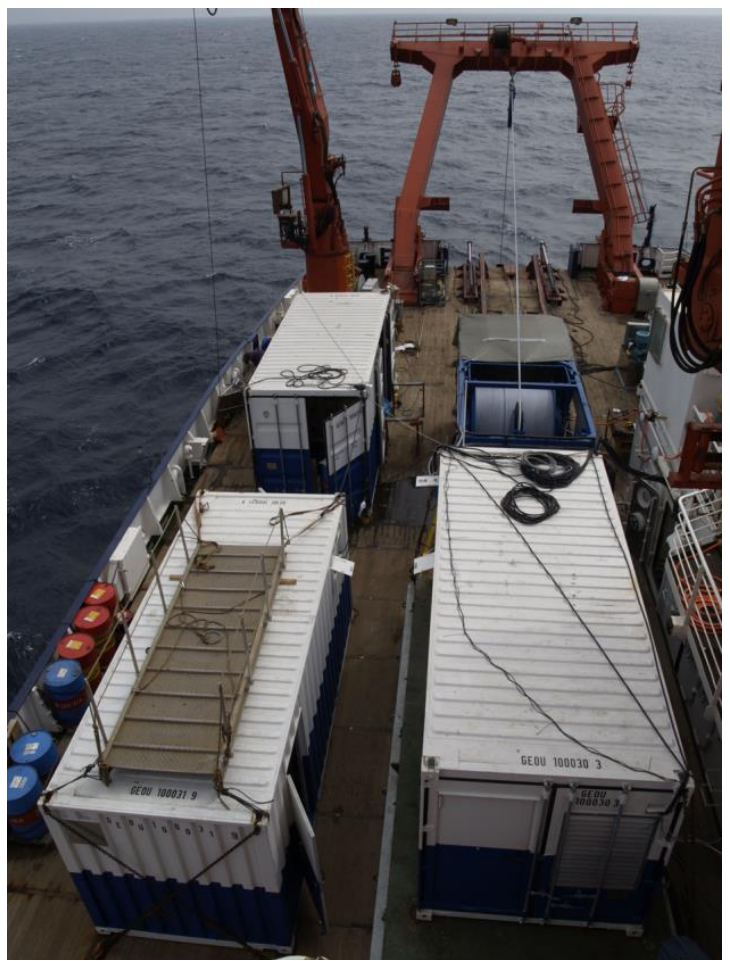

Fig. 3. View toward the stern on the working deck of the research vessel Meteor during deployment of the MeBo. At the front of the picture are the workshop and control containers, behind them the drill-pipe storage and winch, and behind those the launch and recovery system for the MeBo (photo: V. Diekamp, Marum).

The system comprises the drill rig, the winch with $2500 \mathrm{~m}$ of armoured special cable (umbilical), a launch and recovery system (MeBo-LARS), the control unit, a workshop with replacement parts, and storage for the drill pipe (Fig. 1). The control unit, workshop and drill-pipe storage are each accommodated in a $20 \mathrm{ft}(6.058 \mathrm{~m})$ shipping container. The winch is in a transport frame the same size as a $20 \mathrm{ft}$ shipping container. The drill rig and the MeBo-LARS are each stowed in a $20 \mathrm{ft}$ open-top shipping container, with the LARS having to be disassembled for storage and transport. The containerized transport concept allows for quick and efficient worldwide transportation of the system as well as the rapid assembly and breakdown on the research vessel being used (Fig. 3).

The MeBo is about $6.6 \mathrm{~m}$ tall $(5.6 \mathrm{~m}$ without lifting beam for transportation) and has four supporting feet that are lowered before landing on the sea floor to ensure the stability of the rig on a soft or uneven bottom (Fig. 4). The umbilical is used for setting the drill rig down on the sea floor and retrieving it onto the ship after coring is completed. With the system's present umbilical the MeBo can be deployed at water depths down to $2000 \mathrm{~m}$. Copper wires and optical fibres in the centre of the umbilical are used for energy supply to the drill rig and for data transfer between the rig and the control container. 


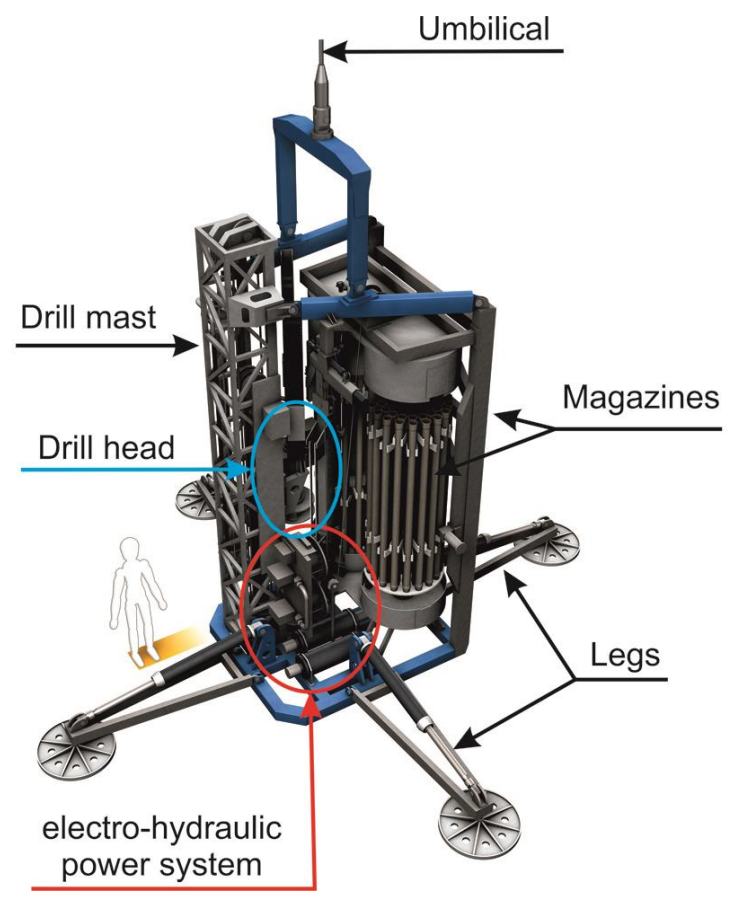

Fig. 4. Schematic overview of the major components of the MeBo (drawing: dibi Multimedia).

The MeBo is hydraulically powered. Four hydraulic pumps powered by two electric motors provide a working pressure of up to 207 bar greater than the ambient pressure. The motors run at a voltage of $3000 \mathrm{~V}$ and have a power of $65 \mathrm{~kW}$ each. We use the high voltage in order to minimize the loss of power during transmission within the $2500 \mathrm{~m}$-long umbilical. Several underwater cameras and sensors are used to monitor the drilling process.

The central element of the MeBo is the feed system with the drill head (Fig. 4). It includes the mast as a guide for the carriage, which is cable-driven by the hydraulic feed cylinder. The feed system supplies the necessary thrust for drilling and pushing the drill string into the hole, as well as for disassembling the drill string later. The drill head provides rotation and the necessary torque for screwing the drill pipe together and for the rotary drilling. It has a hollow spindle to allow the flushing water into the drill string with the help of the flushing water pump. We flush with sea water to cool the drill bit and to wash the loose drill cuttings out of the hole.

The necessary core barrels and drill pipe are stored in two rotating magazines. Depending on the geology of the subsurface, these magazines can be loaded with different kinds of core barrels. A loading arm is used to grab the required pipe as well as for putting it back into the magazines for storage. This is used in combination with a stationary foot clamp to hold the drill string, and a rotating clamp on the drill head to assemble and break down the drill string. In conventional
Table 1. Specification and capabilities of the MeBo.

\begin{tabular}{ll}
\hline Height & $5.6 \mathrm{~m}$ (transport), 6.6 m (work) \\
Footprint (vertical) & $2.3 \mathrm{~m} \times 2.6 \mathrm{~m}$ (legs raised), \\
& $7.0 \mathrm{~m} \times 7.3 \mathrm{~m}$ (legs extended) \\
Weight in air & Approximately 10 \\
Weight in water & Approximately $7 \mathrm{t}$ \\
Maximum operation depth & $2000 \mathrm{~m}$ b.s.l. \\
Maximum sampling depth & $80 \mathrm{~m}$ \\
Drill tool size & HWL (wireline) \\
Run length & $2.35 \mathrm{~m}$ \\
Core diameter & $57-65 \mathrm{~mm}$ \\
Maximum push thrust & $5 \mathrm{t}$ \\
Maximum rotary speed & $400 \mathrm{rpm}$ \\
Hydraulic power & $130 \mathrm{~kW}$ \\
\hline
\end{tabular}

drilling techniques a second stationary clamp is necessary for casing pipe, which is needed to stabilize the hole.

\section{Wireline drilling technique}

To our knowledge, MeBo is the first remote-controlled deep sea drill rig that uses the wireline drilling technique. With this method, after penetration of one core length $(2.35 \mathrm{~m}$ is used for the MeBo) the core barrel holding the cored sample is pulled up through the drill string. For this, a steel cable with an "overshot" (grabbing device) is dropped into the drill string after the drill head is released from the string (Fig. 5). When the core barrel is pulled out of the drill string the overshot is released and the core barrel with the core sample is placed into the magazine. The loading arm takes a new empty core barrel from the magazine and inserts it into the drill string. The inner core barrel is dropped through the drill string, its fall moderated by the water in the string, and at the bottom it is stopped by a shoulder ring in the drill pipe. After lengthening the drill string by an additional joint of pipe (drill rod) from the magazine, and screwing it into the bottom-hole assembly, the next core can be drilled.

Wireline drilling is often used in drilling systems on land. This method is considerably faster than conventional drilling, which requires breaking down the complete drill string after each penetration of a single core length to retrieve the core (McGinnis, 2009). In wireline drilling there is no need for an additional casing pipe to stabilize the hole because the drill string remains in the hole for the duration of the drilling process. This is especially important in soft formations to avoid the risk of hole collapse while the core is being retrieved.

The advantages of wireline drilling are evident, and were discussed at the workshop "Requirements for robotic underwater drills in US marine geologic research" in 2000 (Sager et al., 2003). In fact, the first prototype of a robotic drill rig for deployment on the sea floor, the MARICOR, was designed for wireline drilling. This system, developed by Atlas Copco, included an elevator system with which the core was 


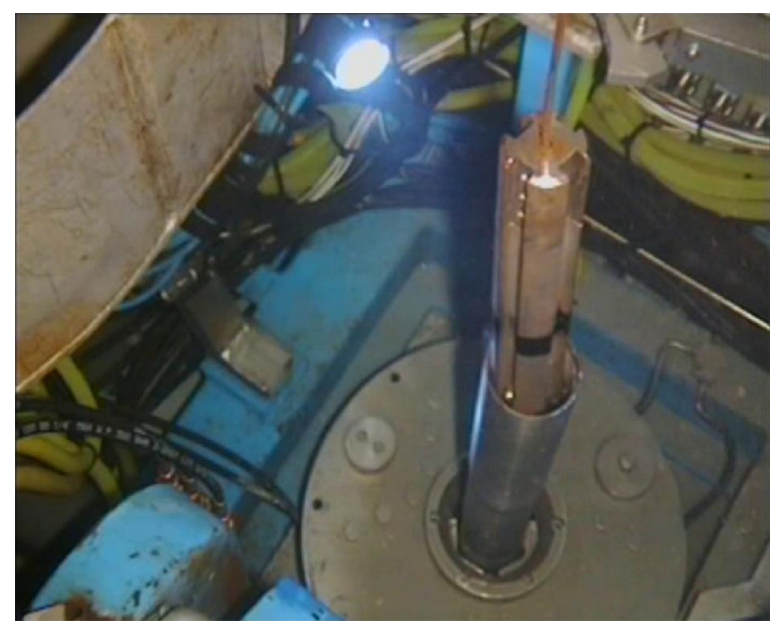

Fig. 5. View of the lower fixed foot clamp of the MeBo. The "overshot" is lowered into the drill string on a steel cable (photo: Marum).

pulled up to the deck of the research vessel immediately after it was drilled. The MARICOR project, however, was cancelled after its first trials (A. Oden, personal communication, 2003). All subsequent remote-controlled drill rigs that were developed up to 2007 for use on the sea floor (BMS, PROD, Rovdrill) use the conventional drilling procedure. Because wireline drilling involves a much higher complexity of operational steps, we at MARUM also initially decided to configure the MeBo for conventional coring. After four successful research expeditions with the MeBo through 2007 (Freudenthal and Wefer, 2007), we undertook the further developmental decision to upgrade the MeBo for use with the wireline technique.

In contrast to land-based drilling systems, remotecontrolled operation of wireline drilling cannot be manually supported. During the upgrade of the MeBo for use with wireline drilling, special attention was therefore given to the processes that are normally supported by the drill foreman on the rig. These include guiding the overshot into the drill string with an additional manipulator, checking the landing of the inner core barrel on the shoulder ring, secure winding of the winch for the cable, releasing the overshot from the core barrel after retrieval from the drill string (Freudenthal et al., 2012) and preparation of the overshot for the next application.

Due to the space saved in magazine storage for the additional pipe needed for conventional drilling, the maximum drilling depth is increased from $50 \mathrm{~m}$ to over $80 \mathrm{~m}$ with the wireline method (Table 2). The advantages of the wireline method have been demonstrated on 10 expeditions with the MeBo since 2008. Average core recovery rates were close to $80 \%$ in different types of geologies including hemipelagic muds, gas-hydrate-bearing sediments, sands, glacial till and carbonate rock. Since wireline coring tools were initially developed for hard rock drilling, we developed special adap-
Table 2. Comparison of drill-pipe sizes used by the MeBo for conventional and wireline drilling.

\begin{tabular}{lrr}
\hline & Conventional & Wireline \\
\hline Pipe size & $\mathrm{T} 2-101$ & $\mathrm{HWL}$ \\
Drilling diameter & $103 \mathrm{~mm}$ & $103 \mathrm{~mm}$ \\
Core diameter & & \\
Hard rock & $84 \mathrm{~mm}$ & $65 \mathrm{~mm}$ \\
Sediment & $80 \mathrm{~mm}$ & $57 \mathrm{~mm}$ \\
Core length & $3000 \mathrm{~mm}$ & $2350 \mathrm{~mm}$ \\
Maximum drilling depth & $\sim 50 \mathrm{~m}$ & $\sim 80 \mathrm{~m}$ \\
\hline
\end{tabular}

tions for improving the core recovery for soft sediments. Examples of cores collected in different types of sediments are shown in Fig. 6.

\section{Auxiliary equipment}

An autonomous probe for obtaining bore-hole measurements has also been developed for use with the MeBo. In a procedure called logging while tripping, the probe, equipped with its own energy source and data storage, is lowered into the drill string after the last core barrel has been retrieved. After the probe has landed on the shoulder ring at the bottom of the hole, the drill string is pulled out and disassembled. The probe, while being raised with the drill string, continuously measures the geophysical properties of the borehole and the in situ sediments and rocks. Major advantages of the loggingwhile-tripping method are a minimum time requirement for the borehole logging since the drill string has to be tripped out anyway as well as the capability of logging unstable formations since the drill string stabilizes the drilled hole during the logging.

Figure 7 shows the results of core drilling and borehole logging at station GeoB 16602 drilled during the RV Sonne expedition SO221 in May 2012 in the South China Sea. One gravity core and three MeBo deployments were conducted within about $100 \mathrm{~m}$ distance at the continental slope of the South China Sea in $950 \mathrm{~m}$ water depth. A drilling depth of more than $80 \mathrm{~m}$ was reached by flushing through the upper $10 \mathrm{~m}$ (reach of the gravity corer) and by core-drilling below. The parallel holes were drilled in order to get more sample material and close gaps in the drilling profile. By splicing the records a continuous profile is obtained for palaeoclimate reconstructions in this area sensitive to changes in the South East Asian monsoon system. During two of the MeBo deployments, bore-hole measurements were conducted with a spectrum gamma ray probe in the logging-while-tripping mode. This probe measures the natural gamma ray signal and analyses the spectrum with respect to the concentrations of the three natural gamma-ray-emitting elements potassium, uranium and thorium. The total gamma ray counts are calibrated by an artificial radioactive formation. Formation 


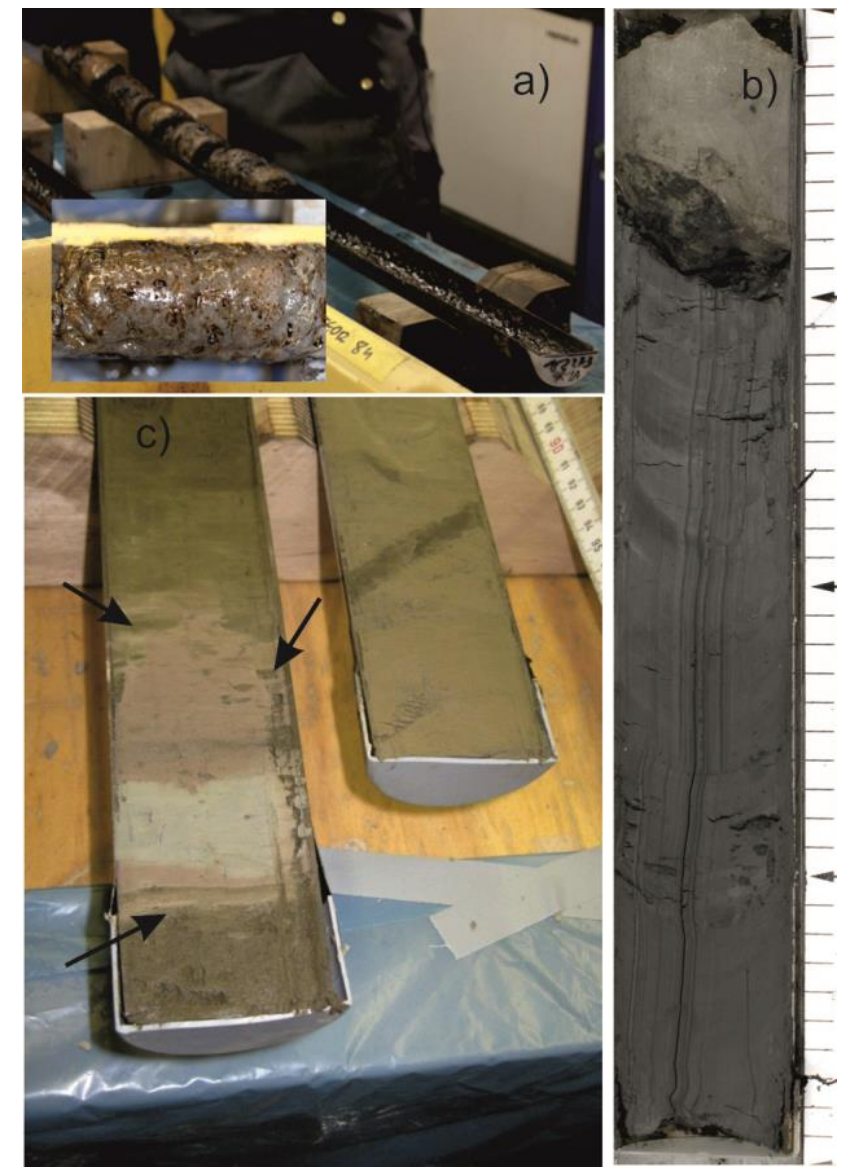

Fig. 6. High-quality cores drilled with the MeBo from massive gas hydrate layers (a), and hemipelagic muds containing authigenic carbonate precipitates (b) and ash layers (c). Arrows point to sharp contact at the base of the ash layer and bioturbation structures at the top, which are indicators of minimum disturbance of the sediments during drilling. (photos: Marum).

gamma ray signal is expressed in the internationally accepted gAPI unit (Ellis and Singer, 2007). A close correlation of the logging profiles is observed between the independently acquired profiles at this site. Natural gamma ray signal (NGR) ranges from 44 to $90 \mathrm{gAPI}$. The variations in NGR are mainly attributed to changes in concentrations of potassium (0.5$1.6 \%)$ and thorium $(4.1-13.0 \mathrm{ppm})$, whereas uranium concentrations are fairly low (1.2-3.1 ppm).

Clays are the main host minerals for thorium and potassium in marine sediments. The variability in NGR can therefore be interpreted as an indicator of changes in terrestrial sediment input into the South China Sea at the two sites. Since the monsoon system is a key factor controlling weathering and terrigenous material transport by rivers, the borehole logging results will help in reconstructing past climate changes in that area.

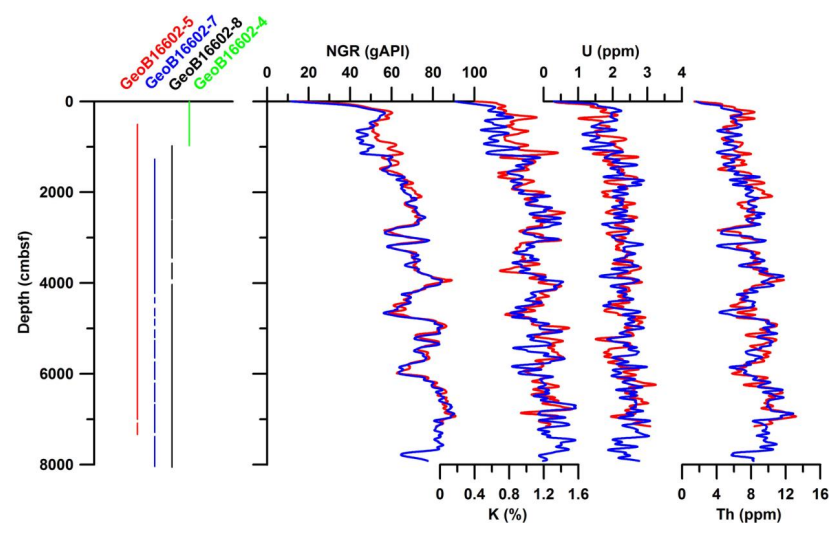

Fig. 7. Core recovery with a gravity core (GeoB16602-4) and three separate MeBo deployments (GeoB16602-5, GeoB16602-7, GeoB16602-8) and borehole logging results of MeBo deployments GeoB16602-5 and GeoB16602-7 at the continental slope of the South China Sea at $950 \mathrm{~m}$ water depth.

Borehole instrumentation and the hydraulic sealing of the borehole against the overlying ocean body with a CORK (circulation obviation retrofit kit) is required for long-term monitoring of borehole pressure changes related, for example, to earthquakes and fluid migration within the sediments (Becker and Davies, 2005; Kopf et al., 2011). An autonomous MeBo-CORK instrument was developed that can be deployed with the MeBo after core drilling is completed (Kopf et al., 2013). It was installed in a custom-built MeBo drill string termination and deployed for the first time in June 2012 during an expedition of the research vessel Sonne (Fig. 8). It contained pressure and temperature transducers in the borehole as well as outside the borehole for sea floor reference. This instrument also includes a data logger, a battery unit and an acoustic modem for data transfer. Unlike other CORK systems the MeBo approach does not require installation assistance by ROVs (Becker and Davies, 2005) and is therefore versatile to install.

\section{MeBo operations}

Since its development in 2004/2005 the MeBo was deployed during 14 expeditions on 5 different multi-purpose research vessels. These vessels include the $65.5 \mathrm{~m}$-long Irish vessel RV Celtic Explorer, the 94.8 to $97.6 \mathrm{~m}$-long German research vessels RV Maria S. Merian, RV Meteor and RV Sonne, and the $107.6 \mathrm{~m}$-long French vessel RV Pourquoi Pas? (Table 3). A research vessel suitable for the deployment of the MeBo needs an A-frame strong enough for lifting the drill rig (weight in water is $7 \mathrm{t}$ plus $1-2 \mathrm{t}$ magazine loading plus $3 \mathrm{t}$ per kilometre of umbilical weight) at dynamic conditions. A careful catenary management in order to prevent twisting of the umbilical depends on good navigation capabilities of the research vessel, preferably using dynamic positioning (DP). 
Table 3. Vessels used so far for the operation of the MeBo.

\begin{tabular}{|c|c|c|c|c|}
\hline $\begin{array}{l}\text { Research } \\
\text { Vessel }\end{array}$ & $\begin{array}{r}\text { Length } \\
{[\mathrm{m}]}\end{array}$ & $\begin{array}{l}\text { Gross } \\
\text { tonnage }\end{array}$ & $\begin{array}{r}\text { A-Frame SWL } \\
{[\mathrm{kN}]}\end{array}$ & $\begin{array}{l}\text { Expeditions } \\
\text { [Name (year), chief scientist, area] }\end{array}$ \\
\hline Celtic Explorer & 65.5 & 2425 & 250 & $\begin{array}{l}\text { CE0511 (2005), Freudenthal, Baltic Sea } \\
\text { CE0619 (2006), Murray, off Ireland } \\
\text { CE0810 (2008), Wheeler, off Ireland }\end{array}$ \\
\hline Maria S. Merian & 94.8 & 5573 & 200 & $\begin{array}{l}\text { MSM04/4 (2007), Freudenthal, off Morocco } \\
\text { MSM15/3 (2010), Huhn, off Sicily } \\
\text { MSM30 (2013), Hanebuth, W. Barents Sea }\end{array}$ \\
\hline Meteor & 97.5 & 4280 & 200 & $\begin{array}{l}\text { M65/3 (2005), Wefer, off Morocco } \\
\text { M76/1 (2008), Zabel, off Namibia } \\
\text { M78/3 (2009), Wefer, off Argentine } \\
\text { M84/2 (2011), Bohrmann, Black Sea }\end{array}$ \\
\hline Sonne & 97.6 & 3557 & 100 & $\begin{array}{l}\text { SO211 (2010), Hebbeln, off Chile } \\
\text { SO221 (2012), Mohtadi, South China Sea } \\
\text { SO222 (2012), Kopf, off Japan }\end{array}$ \\
\hline Pourquoi Pas? & 107.6 & 7854 & 220 & GUINECOMeBo (2011), Sultan, off Nigeria \\
\hline
\end{tabular}

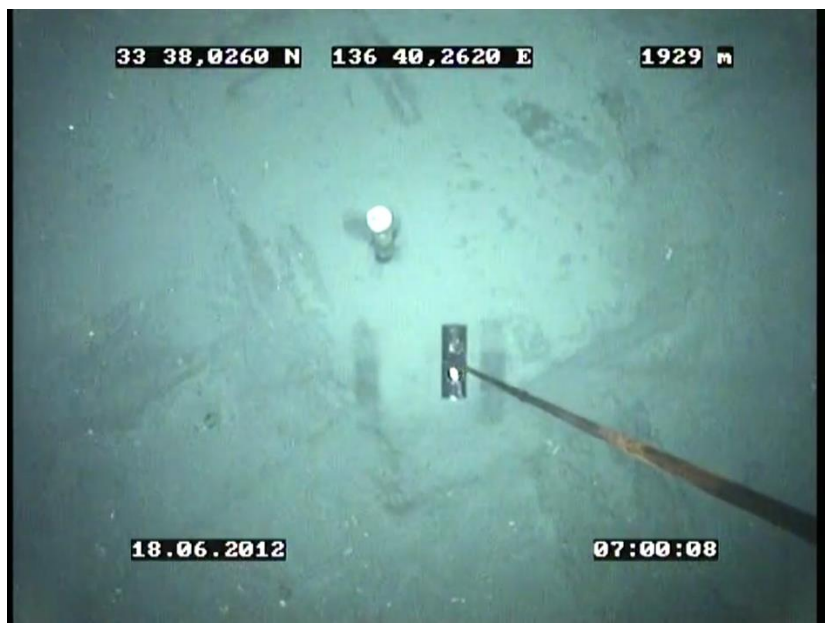

Fig. 8. Picture of a MeBo-CORK installed in June 2012 with the MeBo. The picture was taken a few days after installation with a towed camera sled, the Ocean Floor Observation System (OFOS) of the research vessel Sonne. Note the imprint of the base frame and of the legs of the MeBo on the sea floor. The distance weight on a $2 \mathrm{~m}$ rope in the lower right of the picture belongs to the camera sled and assists the winch driver in assessing distance to sea floor (photo: Marum).

A length of free deck space of approximately $16-20 \mathrm{~m}$ is required in front of the A-frame for installation of the launch and recovery system of the MeBo and the $30 \mathrm{t}$ lift umbilical winch. Additional deck space is needed for storing the workshop container, the drill tool container and the control container. The workshop container hosts spare parts and tools for maintenance and repair of the system. Core barrels and rods, as well as drill bits and core catchers, for different types of geology are stored in the drill tool container. The operator console includes a video wall for displaying the images of eight sub-sea cameras mounted on the drill rig as well as three deck cameras and belongs to the fixed installations within the control container. Together with the launch and recovery system, the winch, the drill rig and the containers, the payload of the MeBo system sums up to approximately $90 \mathrm{t}$.

The MeBo is operated by a total of ten technicians. Three shifts of two operators each alternate in running the drill rig $24 \mathrm{~h}$ per day. Four technicians assist the launch and recovery, prepare the drill tools, change the loading of the magazines and conduct the maintenance and repair (if required) when the MeBo is on deck. The turnover time between two deployments typically takes $12 \mathrm{~h}$, while a drilling operation down to $80 \mathrm{~m}$ below sea floor in soft sediments requires 30 to $36 \mathrm{~h}$ operation time.

Approximately $2000 \mathrm{~m}$ of drilling has been done so far during 101 deployments (conventional and wireline drilling) at water depths between 10 and $2050 \mathrm{~m}$. The average core recovery was $73 \%$ in different types of geologies including sedimentary and crystalline rocks, glacial tills, sands and hemiplegic muds. Recovery rates of more than $90 \%$ were achieved especially in hard rock formations and cohesive sediments, while sands and gravels are difficult to sample with the wireline rotary drilling method.

Especially when shallow drillings of less than $100 \mathrm{~m}$ below sea floor are required, the MeBo provides a cost- and time-effective alternative to the use of drilling vessels. Even in difficult geologies like fractured rock or alternating layers of indurated and unconsolidated sediments, the MeBo showed good drilling results since drilling from a stable platform on the sea bed provides optimal control over the drilling parameters, especially over weight on the bit. High-quality cores drilled with the MeBo provided ground truth for the interpretation of seismic profiles (Krastel et al., 2011). MeBo cores drilled off Sicily were used for geotechnical testing of sediments for slope stability research (Ai et al., 2013). Long, 
continuous records for palaeoceanographic research can be acquired by double-hole drilling with $\mathrm{MeBo}$ and subsequent splicing of the records. Using this method a $970000 \mathrm{yr}$ record of past changes in intermediate water mass characteristics in the SE Pacific was analysed based on cores drilled with the MeBo off Chile (Martínez-Méndez et al., 2013).

So far the MeBo has been operated in the Atlantic and Pacific Ocean in low and high latitudes as well as in the Black Sea, Mediterranean Sea and Baltic Sea. The MeBo system is operated worldwide with reasonable logistical effort since it is operated on vessels of opportunity.

\section{MeBo200}

Based on the experience of the successful MeBo development and deployments, we are presently developing, with funding from the Federal Government of Germany (Ministery of Education and Research, BMBF), the secondgeneration MeBo: MeBo200. This drill rig will be able to conduct core drilling down to $200 \mathrm{~m}$ below sea floor. Its development is within a cooperation of the company BAUER Maschinen $\mathrm{GmbH}$ - responsible for the drill mechanics and hydraulics - and MARUM. By optimizing the interplay between loading arm, chucks and the feeding system, we were able to increase the stroke length from 2.35 to $3.5 \mathrm{~m}$. The MeBo200 is mounted in a $20 \mathrm{ft}$ transport frame, allowing for standard container shipping. As a result of this it was possible also to increase the loading capacity of the magazines, which together with the increased stroke length results in a substantial increase of the drilling depth capabilities.

\section{Summary and conclusions}

The sea floor drill rig MeBo is a robotic drill rig that is deployed on the sea bed and remotely controlled from the research vessel. H-size drill tools for wireline core drilling are stored in two magazines on the drill rig and allow for drilling down to $80 \mathrm{~m}$ below sea floor for coring soft sediments as well as hard rocks. A $2500 \mathrm{~m}$-long umbilical is used for lifting the $10 \mathrm{t}$ device as well as for energy supply and data transfer. The MeBo system comprises the drill rig, the lift umbilical winch, the control station and the launch and recovery system, and is transported in six containers. It is deployed worldwide from German and international research ships and proved its capability during 14 scientific expeditions between 2005 and 2012. Average core recovery rates of $73 \%$ were achieved in different types of geologies including hemipelagic muds, gas-hydrate-bearing sediments, sands, glacial till and carbonate rock. Besides core drilling, the MeBo is used for borehole logging in the logging-whiletripping mode as well as for the instrumentation of boreholes for long-term monitoring of pressure and temperature changes within the sediments. Experience with the MeBo is now being used for developing a second-generation drill rig called MeBo200, which is capable of drilling down to a depth of $200 \mathrm{~m}$ below sea floor.

Acknowledgements. The authors thank the MARUM personnel for their valuable contributions to the development and operation of the MeBo. Development of the MeBo was supported by the Bundesministerium für Bildung und Forschung (Federal Ministry of Education and Research) and by the State of Bremen. Operational support was provided by funding from the DFG (DFG-Forschungszentrum/Excellenzcluster "The Ocean in the Earth System"), by the Senatskommission für Ozeanographie (Senate Commission for Oceanography) and by the coordination headquarters for the Meteor/Merian. We also thank the captains and crews of the research ships Meteor, Maria S. Merian, Sonne, Pourquoi Pas? and Celtic Explorer for their support during the research expeditions with the MeBo.

Edited by: A.-M. Harri

\section{References}

Ai, F., Kuhlmann, J., Huhn, K., Strasser, M., and Kopf, A.: Submarine slope stability assessment of the central Mediterranean continental margin: the Gela Basin, in: Submarine Mass Movements and Their Consequences, edited by: Krastel, S., Behrmann, J.-H., Völker, D., Stipp, M., Berndt, C., Urgeles, R., Chaytor, J., Huhn, K., Strasser, M., and Harbitz, C. B., Springer, 225-238, 2013.

Becker, K. and Davis, E. E.: A review of CORK designs and operations during the Ocean Drilling Program, Proc. IODP, 301, doi:10.2204/iodp.proc.301.104.2005, 2005.

Ellis, D. V. and Singer, J. M.: Well logging for earth scientists, 2nd Edn., Springer, Dordrecht, 692 pp., 2007.

Freudenthal, T. and Wefer, G.: Scientific drilling with the sea floor drill rig MeBo, Ocean Drilling, 5, 63-66, 2007.

Freudenthal, T., Mühlenbrock, S., and Cwiekala, T.: Hakenfänger, Patent No. DE102008002835 B4 2012.09.06, 2012.

Hebbeln, D.: State of the art and future prospects of scientific coring and drilling of marine sediments, in: Ocean Margin systems, edited by: Wefer, G., Billet, D., Hebbeln, D., Jørgensen, B. B., and van Weering, T. C. E., Springer, 57-66, 2003.

Ishibashi, J.-I., Marumo, K., Maruyama, A., and Urabe, T: Direct access to the sub-vent biosphere by shallow drilling, Oceanography, 20, 24-25, 2007.

Johnson, H. P.: Next generation of sea floor samplers, EOS, 82, 6566, 1991.

Kopf, A., Hammerschmidt, S., Saffer, D. M., Lauer, R., Davis, E. E., LaBonte, A., Meldrum, R., Heesemann, M., Macdonald, R., Toczko, S., Wheat, C. G., Jannasch, H., Edwards, K., Haddad, A., Orcutt, B., Villinger, H., Araki, E., Kitada, K., Kimura, T., and Kido, Y.: The SmartPlug and GeniusPlug: Simple retrievable observatory systems for NanTroSEIZE borehole monitoring, Proc. IODP, 332, doi:10.2204/iodp.proc.332.105.2011, 2011

Kopf, A., Asshoff, K., Belke-Brea, M., Bergenthal, M., Bohrmann, G., Bräunig, A., Düssmann, R., Feseker, T., Fleischmann, T., Franke, P. D., Geprägs, P., Hammerschmidt, S., Heesemann, B., Herschelmann, O., Hüpers, A., Ikari, M. J., Kaszemaik, K. M., Kaul, N., Kimura, T., Kitada, K., Klar, S., Lange, M., Madison, M., Mai, A. H., Noorlander, C., Pape, T., Rehage, R., 
Reuter, C., Reuter, M., Rosiak, U. D., Schmidt, W., Seiter, C., Spiesecke, U., Stachowski, A., Steiner, A., Takanori, O., Tryon, M., Vahlenkamp, M., Wei, J., Wintersteller, P., and Zarrouk, M. K.: Report and preliminary results of RV Sonne CRUISE SO222: MEMO - MeBo drilling and in situ Long-term Monitoring in the Nankai Trough accretionary complex, Japan, Berichte aus dem Fachbereich Geowissenschaften der Univ. Bremen, 297, 121 pp., 2013.

Krastel, S., Wefer, G., Hanebuth, T. J. J., Antobreh, A. A., Freudenthal, T., Preu, B., Schwenk, T., Strasser, M., Violante, R., Winkelmann, D., and M78/3 Shipboard Scientific Party: Sediment Dynamics and Geohazards off Uruguay and the de la Plata River region (Northern-Argentina, Uruguay), Geo-Mar. Lett., 31, 271283, 2011.

MacLeod, C. J., Escartín, J., Banerji, D., Banks, G. J., Gleeson, M., Irving, D. H. B., Lilly, R. M., McCaig, A. M., Niu, Y., Allerton, S., and Smith, D. K.: Direct geological evidence for oceanic detachment faulting: The Mid-Atlantic Ridge, $15^{\circ} 45^{\prime} \mathrm{N}$, Geology, 30, 879-882, 2002.

Martínez-Méndez, G., Hebbeln, D., Mohtadi, M., Lamy, F., De PolHolz, R., Reyes-Macaya, D., and Freudenthal, T.: Changes in the advection of Antarctic Intermediate Water to the northern Chilean coast during the last $970 \mathrm{kyr}$, Paleoceanography, 28, 112, doi:10.1002/palo.20047, 2013.

McGinnis, T.: Seafloor Drilling, in: Drilling in extreme environments, edited by: Bar-Cohen, Y. and Zacny, K., Wiley, 309-345, 2009.
Pallanich, J.: Prod probes Statoil's seabed soils, Offsh. Engin., February 2010, 42-44, 2010.

Sager, W., Dick, H., Fryer, P., and Johnson, H. P.: Requirements for robotic underwater drills in U.S. marine geological research. Report from a workshop, 3-4 November 2000, http://usssp-iodp. org/workshop/robotic-underwater-drills/ (last access: 19 December 2013), 2003.

Spencer, A., Remmes, B., and Rowson, I.: A fully integrated solution for the geotechnical drilling and sampling of seafloor massive sulfide deposits, Proceedings Offshore Technology Conference OTC 21439, 2011.

Stakes, D. S., Holloway, G. L., Tucker, P., Dawe, T. C., Burton, R., McFarlane, J. A. R., and Etchemendy, S.: Diamond rotary coring from an ROV or submersible for hardrock sample recovery and instrument deployment: The MBARI multiple-barrel rock coring system, Mar. Technol. Soc. J., 31, 11-20, 1997.

Stuart, S.: The remote robot alternative, International Ocean Systems , 8, 23-25, 2004.

Wilson, M.: Drilling at sea, Earthwise, 23, 32-33, 2006.

Yetginer, A. G. and Tjelta, T. I.: Seabed drilling vs surface drilling - a comparison, in: Frontiers in Geotechnics II, edited by: Gourvenc, S. and White, D., Taylor \& Francis Group, 327-331, 2011. 